\title{
New diagnostic approach for ocular tuberculosis by ELISA using the cord factor as antigen
}

\author{
Jun-ichi Sakai, Suguru Matsuzawa, Masahiko Usui, Ikuya Yano
}

\begin{abstract}
Backgroundlaims-Diagnosis of ocular tuberculosis is difficult, particularly the retinal vasculitis type, because most cases occur without concurrent active pulmonary tuberculosis. Recently, it has been reported that detection of antibodies against purified cord factor (trehalose6,6'-dimycolate, TDM), the best studied, most antigenic, and most abundant cell wall component of tubercule bacilli, is very useful for rapid serodiagnosis of pulmonary tuberculosis. In this study, an attempt was made to evaluate whether the detection of anticord factor antibody is also useful for diagnosis of ocular tuberculosis and the necessity of antituberculous therapy for tuberculous retinochoroiditis was discussed.
\end{abstract}

Methods-Cases consisted of 15 patients with uveitis and retinal vasculitis, nine patients with presumed ocular tuberculosis, three patients with sarcoidosis, and three patients with Behçet's disease. IgG antibodies against purified cord factor prepared from Mycobacterium tuberculosis $\mathrm{H} 37 \mathrm{Rv}$ were detected by enzyme linked immunosorbent assay.

Results-All cases of clinically presumed ocular tuberculosis were positive, whereas all of the cases of sarcoidosis or Behçet's disease were negative for anticord factor antibodies. When the anticord factor antibody titres were compared on the basis of the presence or absence of previous antituberculosis chemotherapy, the mean anticord factor antibody titre of the untreated group showed a tendency to be higher than in the treated group, but not significantly $(p=0.07)$.

Conclusions-The detection of anticord factor antibody may be useful to support the diagnosis of ocular tuberculosis. Additionally, a positive result for anticord factor antibody may indicate that tubercule bacilli are present in some organ(s) of the patient even in the absence of active systemic disease.

(Br F Ophthalmol 2001;85:130-133)

Tuberculous posterior segment intraocular inflammation, which is the most common ocular involvement of tuberculosis, presents in any of several manifestations, including multifocal choroiditis formed by choroidal tubercles, choroidal granulomas, and retinal periphlebitis. ${ }^{12}$ However, diagnosis of ocular tuberculosis is generally difficult. In most cases the clinician has to rely on a combination of evidence of systemic disease, characteristic ocular findings, and possibly a therapeutic treatment trial to make the diagnosis. Routine tuberculin skin testing using purified protein derivative (PPD) is rarely helpful, because most patients have already received bacille Calmette-Guerin (BCG), especially in Japan, and therefore will show a hypersensitive response to PPD (that is, a positive result is not specific for tuberculosis). Furthermore, ocular tuberculosis may occur in patients with no systemic disease. There are reports of ocular tuberculosis with a negative chest $x$ ray, ${ }^{3}$ or skin test, ${ }^{4}$ or both. ${ }^{5}$ In nearly all reported cases, the diagnosis of intraocular tuberculosis is only presumptive.

Recently, it has been reported that the detection of antibodies against purified cord factor (trehalose-6,6'-dimycolate, TDM), the most characteristic cell wall component of tubercle bacilli and other related acid fast bacteria, is very useful for rapid serodiagnosis of pulmonary tuberculosis. ${ }^{6}$ In this study, we evaluated whether the detection of anticord factor antibody is also useful for diagnosis of ocular tuberculosis and discussed the necessity of antituberculous therapy for tuberculous retinochoroiditis.

\section{Materials and methods}

SUBJECTS AND SERUM SPECIMENS

Fifteen patients with uveitis and retinal vasculitis who visited the uveitis clinic of Tokyo Medical University Hospital in 1998 and 1999 were registered in this study. Nine patients with presumed ocular tuberculosis, three patients with sarcoidosis, and three patients with Behçet's disease were enrolled; the characteristics of each patient are summarised in Table 1. Diagnoses of sarcoidosis and Behçet's disease were based on the criteria of the disease research committee. ${ }^{78}$ A presumption of ocular tuberculosis was made on the basis of the presence of characteristic ocular lesions in the context of evidence of previous exposure to Mycobacterium tuberculosis (all cases were PPD skin test positive). All patients diagnosed as presumed ocular tuberculosis presented with retinal vasculitis, characterised by a relatively 
Table 1 Patient baseline characteristics and anticord factor antibody titres

\begin{tabular}{|c|c|c|c|c|c|c|c|c|c|c|}
\hline $\begin{array}{l}\text { Patient } \\
\text { No }\end{array}$ & $\begin{array}{l}\text { Age } \\
\text { (years) }\end{array}$ & $\operatorname{Sex}$ & $\begin{array}{l}\text { Anterior } \\
\text { uveitis }\end{array}$ & $\begin{array}{l}\text { Retinal } \\
\text { vasculitis }\end{array}$ & $\begin{array}{l}\text { Retinal capillary } \\
\text { non-perfusion }\end{array}$ & $\begin{array}{l}\text { PPD skin } \\
\text { test }\end{array}$ & Chest $x$ ray & Clinical diagnosis & $\begin{array}{l}\text { Titre } \\
(A I)\end{array}$ & Evaluation * \\
\hline 1 & 27 & M & + & + & + & + & normal & Presumed ocular TB & 0.430 & positive \\
\hline 2 & 75 & $\mathrm{~F}$ & + & + & + & + & normal & Presumed ocular TB & 0.700 & positive \\
\hline 3 & 68 & M & + & + & + & + & healed pulmonary TB & Presumed ocular TB & 0.210 & positive \\
\hline 4 & 53 & $\mathrm{~F}$ & + & + & + & + & healed pulmonary TB & Presumed ocular TB & 0.150 & positive \\
\hline 5 & 29 & $\mathrm{M}$ & + & + & + & + & pulmonary TB & Presumed ocular TB & 2.212 & positive \\
\hline 6 & 61 & M & + & + & + & + & normal & Presumed ocular TB & 0.258 & positive \\
\hline 7 & 62 & $M$ & + & + & + & + & normal & Presumed ocular TB & 0.263 & positive \\
\hline 8 & 67 & $\mathrm{~F}$ & + & + & + & + & healed pulmonary TB & Presumed ocular TB & 2.469 & positive \\
\hline 9 & 74 & $\mathrm{~F}$ & + & + & - & + & healed pulmonary TB & Presumed ocular TB & 0.929 & positive \\
\hline 10 & 54 & $\mathrm{~F}$ & + & + & - & - & BHL & Sarcoidosis & 0.098 & negative \\
\hline 11 & 64 & $\mathrm{~F}$ & + & + & - & - & BHL & Sarcoidosis & 0.097 & negative \\
\hline 12 & 45 & $\mathrm{~F}$ & + & + & - & - & BHL & Sarcoidosis & 0.013 & negative \\
\hline 13 & 36 & $M$ & + & + & - & + & normal & Behçet's disease & 0.050 & negative \\
\hline 14 & 34 & $M$ & + & + & - & + & normal & Behçet's disease & 0.070 & negative \\
\hline 15 & 49 & $\mathrm{~F}$ & + & + & - & + & normal & Behçet's disease & 0.081 & negative \\
\hline
\end{tabular}

$\star$ Positive: $\mathrm{AI} \geqslant 0.100$.

mild degree of cellular infiltrate in the anterior chamber and vitreous, periphlebitis, and a marked tendency to peripheral retinal capillary non-perfusion leading to new vessel formation. ${ }^{9}$ Of the nine patients with presumed ocular tuberculosis, only one case had active pulmonary tuberculosis, four appeared to have old pulmonary tuberculosis on chest $x$ ray films, and the others had no systemic disease. At the time when serum samples were obtained, cases 1, 3, and 4 already had a history of antituberculous therapy for suspected ocular tuberculosis (Table 2). Serum samples were obtained after obtaining informed consent from the patients.

ELISA

Cord factor was extracted and purified from a culture of $M$ tuberculosis $\mathrm{H} 37 \mathrm{Rv}$, as reported previously. ${ }^{6}$ The purified cord factor antigen was dissolved in $n$-hexane at a concentration of $0.1 \mathrm{mg} / \mathrm{ml}, 25 \mu \mathrm{l}$ of which was placed in each well of microtitre plates. A serum sample diluted 1:160 was added to each well after blocking with $0.05 \%$ Tween-20 in phosphate buffered saline (PBS-T). Goat antihuman immunoglobulin $G$ labelled with peroxidase and diluted 1:500 with PBS-T was used as the second antibody. The absorption was read with a microplate reader at $492-630 \mathrm{~nm}$.

DATA ANALYSIS

Anticord factor antibody titres were expressed as the absorption difference (AI) - that is, the difference in the absorption between the test serum and the same serum in wells not coated with antigen.

In our previous study, it was decided to record an $\mathrm{AI}$ equal to or above 0.100 as positive. ${ }^{6}$ That is, the mean AI of 100 healthy controls, among whom one person was tuberculin negative and the others were all positive, was 0.016 (the absorption values of healthy controls was distributed between -0.102 and 0.099).

Statistical analysis of data was performed using the Mann-Whitney U test.

\section{Results}

Table 1 shows the ELISA results for the patients. When the cutoff point of AI was set at 0.100 , the nine patients who were given a clinical diagnosis of presumed ocular tuberculosis were all positive. The three patients with sarcoidosis and three patients with Behçet's disease were all negative. In the presumed ocular tuberculosis group, only one case (case 5) had active pulmonary disease, while the other eight had no active systemic disease. The case with active pulmonary disease (case 5) and three of the cases without evidence of active systemic disease (cases 2,8 , and 9) each had a high titre of anticord factor antibody.

When the anticord factor antibody titres were compared on the basis of the presence or absence of previous antituberculosis chemotherapy (Table 2), the mean anticord factor antibody titre of the untreated group (cases 2 and 5-9) showed a tendency to be higher than the mean of the treated group (cases 1, 3, and 4 ), but not significantly $(\mathrm{p}=0.07$, estimated power 0.46).

The anticord factor antibody titres bore no relation to the length of the period from the onset of subjective symptoms until the assay for anticord factor antibody (Table 2).

Table 2 Treatment and outcome in presumed ocular TB

\begin{tabular}{lllllll}
\hline $\begin{array}{l}\text { Patient } \\
\text { No }\end{array}$ & A & $B$ & $\begin{array}{l}\text { Antituberculous } \\
\text { therapy }\end{array}$ & $\begin{array}{l}\text { Laser } \\
\text { photocoagulation }\end{array}$ & Vitrectomy & Outcome \\
\hline 1 & 9 months & + & + & + & + & resolved \\
2 & 1 year over & - & + & - & - & inactive \\
3 & 1 year over & + & + & + & - & inactive \\
4 & 1 year & + & + & - & - & resolved \\
5 & 2 months & - & + & + & - & inactive \\
6 & 2 weeks & - & + & + & - & resolved \\
7 & 2 months & - & + & - & inactive \\
8 & 3 months & - & + & + & inactive \\
9 & 1 year & - & + & - & inactive \\
\hline
\end{tabular}

$\mathrm{A}=$ period from the onset of symptoms until the assay for anticord factor antibody.

$\mathrm{B}=$ presence or absence of antituberculous therapy before the detection of anticord factor antibody. 


\section{Discussion}

As of several years ago it was generally accepted that the implication of tuberculosis as a cause of ocular disease had declined owing to the diminishing incidence of tuberculous infection and advances in the treatment of tuberculosis. However, today much attention is again being paid to tuberculosis as a re-emerging infectious disease in association with an increase in the number of immunocompromised hosts and disregarded care for tuberculosis. ${ }^{10}$

The choroid and retina are probably the most commonly infected intraocular structures as a result of haematogenous dissemination of $M$ tuberculosis, or are the targets of hypersensitivity reactions. However, verification of the participation of this bacterium is difficult, particularly in the type characterised by retinal periphlebitis, which is the most common manifestation of retinal tuberculosis, because most cases occur without concurrent active pulmonary tuberculosis. ${ }^{9}$ Evidence of tuberculous antigen or DNA in the ocular tissues or fluids is required for confirmed diagnosis. Though it is difficult to detect the antigen, the availability of a polymerase chain reaction technique for $M$ tuberculosis using ocular fluids is likely to be helpful. ${ }^{11-13}$ However, the acquisition of ocular fluid is generally impractical for diagnostic purposes, as is chorioretinal endobiopsy. ${ }^{5}$ Moreover, false positive reactions in tuberculin skin testing may occur as a result of recent BCG vaccination, or following infection with antigenically related species, such as Mycobacterium avium intracellulare. Consequently, the diagnosis is practically presumptive, based on characteristic fundal lesions and the coexistence or previous history of tuberculous infection. Therefore, the diagnosis of ocular tuberculosis is difficult, and a new diagnostic approach for this disease has been needed.

The mycobacterial cell wall contains various lipids. Among them, cord factor (trehalose6,6'-dimycolate, TDM) is the most ubiquitous component, and it may be a key molecule for pathogenesis and immunity in tuberculosis. It has been demonstrated that cord factor shows lethal toxicity, granuloma forming activity, adjuvant activity, tumour regressing activity, and non-specific infection prevention activity in experimental animals according to the species and the dosage of cord factor. ${ }^{14}$

It has also been found that antibodies against cord factor are present in the serum of patients with pulmonary tuberculosis and that the detection of anticord factor antibody is very useful for rapid serodiagnosis of pulmonary tuberculosis. ${ }^{6}$ Furthermore, it was reported that the ELISA technique using cord factor had a sensitivity of $81 \%$ and a specificity of $96 \%$ for patients with active and untreated pulmonary tuberculosis, and that the anticord factor antibody titre declined to a normal level as a result of antituberculosis chemotherapy. ${ }^{15}$

In this study, we evaluated whether detection of anticord factor antibody is also useful for the diagnosis of ocular tuberculosis. ELISA using cord factor as the antigen gave satisfactory results in confirming the diagnosis of ocular tuberculosis. That is, all cases of clinically presumed ocular tuberculosis were positive, whereas all cases of sarcoidosis or Behçet's disease were negative. In spite of their common features of uveitis with retinal vasculitis, a clearcut difference was thus ascertained between ocular tuberculosis and the other diseases.

All cases meeting our criteria - that is, suggestive of relatively typical ocular tuberculosis and consistent with published reports of retinal vasculitis associated with tuberculosis, ${ }^{2916}$ and in which no other entity was suggested, were consecutively enrolled in this study. Thus we attempted to eliminate selection bias.

Maekura et $a l^{15}$ reported that the antibody titres of patients with active pulmonary tuberculosis tended to decrease because of antituberculosis combination chemotherapy, and they reached the same level as that of non-tuberculous control subjects within 3 years. This finding suggests the possibility that determination of the anticord factor antibody titre is useful for deciding therapeutic strategy. Consequently, a positive result for anticord factor antibody may indicate that tubercle bacilli are present in some organ(s) of the patient, and that institution of antituberculosis chemotherapy must be considered. In our study, the mean anticord factor antibody titre of the untreated group was higher than that of the treated group, and antituberculosis chemotherapy had resulted in a good prognosis for the presumed ocular tuberculosis (ischaemic retinal periphlebitis) (Table 2). A relation between retinal vasculitis and tuberculosis is generally accepted, ${ }^{29} 16$ yet the precise nature of that relations has not been established. Though the question is unresolved as to whether the retinal vasculitic lesions contain active tubercle bacilli or reflect a hypersensitive response, we surmise that systemic antitubercular medication should be given to most patients with presumed ocular tuberculosis.

In conclusion, the detection of anticord factor antibody was very useful for supporting the diagnosis of ocular tuberculosis. Additionally, a positive result for anticord factor antibody may indicate that tubercle bacilli are present in some organ(s) of the patient even in the absence of active systemic disease and possibly stimulate the immune system as an antigen in the pathogenesis of retinal vasculitis.

\footnotetext{
The authors are indebted to Professor J Patrick Barron of the International Medical Communications Center of Tokyo Medical University for his review of this manuscript.

1 Forrester JV, Okada AA, BenEzra D, et al, eds. Tuberculosis. In: Posterior segment intraocular inflammation: guidelines. The Hague: Kugler, 1998:32-5.

2 Dunn JP, Helm CJ, Davidson PT. Tuberculosis. In: Pepose JS, Holland GN, Wihelmus KR, eds. Ocular infection and immunity. St Louis: Mosby, 1996:1405-20.

3 Mansour AM, Haymond R. Choroidal tuberculomas without evidence of extraocular tuberculosis. Graefes Arch Clin Exp Ophthalmol 1990;228:382-5.

4 Darrell RW. Acute tuberculosis panophthalmitis. Arch Ophthalmol 1967;78:51-4.

5 Barondes MJ, Sponsel WE, Stevens TS, et al. Tuberculous choroiditis diagnosed by chorioretinal endobiopsy. $A m$ f Ophthalmol 1991;112:460-1.

$6 \mathrm{He} \mathrm{H}$, Oka S, Han Y, et al. Rapid serodiagnosis of human mycobacteriosis by ELISA using cord factor (trehalose6,6'-dimycolate) purified from Mycobacterium tuberculosis as antigen. FEMS Microbiol Immunol 1991;76:201-4.
} 
7 Criteria for the diagnosis of sarcoidosis. Fapanese fournal of Sarcoidosis and Other Granulomatous Disorders 1999;19:1217.

8 International Study Group for Behçet's disease. Criteria for the diagnosis of Behçet's disease. Lancet 1990;335:107880.

9 Rosen PH, Spalton DJ, Graham EM. Intraocular tuberculosis. Eye 1990;4:486-92.

10 World Health Organization. Communicable disease. Global tuberculosis control. WHO Report 1999. WHO/CDC/TB/ 99. Geneva: WHO, 1999:259.

11 Kotake S, Kimura K, Yoshikawa K, et al. Polymerase chain reaction for the detection of Mycobacterium tuberculosis in ocular tuberculosis. Am f Ophthalmol 1994;117: $805-6$.
12 Biswas J, Therese L, Madhavan $\mathrm{HN}$. Use of polymerase complex DNA from vitreous sample of Eales' disease (letcomplex DNA from vitreous sampl

ter). Br F Ophthalmol 1999;83:994.
13 Madhavan HN, Therese L, Gunisba P, et al. Polymerase chain reaction for detection of Mycobacterium tuberculosis in epiretinal membrane in Eales' disease. Invest Ophthalmol Vis Sci 2000;41:822-5.

14 Yano I. Cord factor. Kekkaku 1998;73:37-42.

15 Maekura R, Nakagawa M, Nakamura Y, et al. Clinical evaluation of rapid serodiagnosis of pulmonary tuberculosis by ELISA with cord factor (trehalose-6,6'-dimycolate) as antigen purified from Mycobacterium tuberculosis. Am Rev Respir Dis 1993;148:997-1001.

16 Fountain JA, Werner RB. Tuberculous retinal vasculitis. Retina 1984;4:46-50. 